DOI: 10.2478/v10025-012-0007-y

JOURNAL OF WATER

AND LAND DEVELOPMENT

J. Water Land Dev. No. 15, 2011: 73-82

\title{
Protective significance of meadows and pastures for the natural environment of the Western Carpathians (as an example of the Upper Dunajec River basin)
}

\author{
Sylwester SMORON', Marek KOPACZ, Stanisław TWARDY, \\ Antoni KUŹNIAR
}

Institute of Technology and Life Sciences in Falenty, Małopolska Research Centre in Kraków, 31450 Kraków, ul. Ułanów 21B, phone/fax +48 12 412-84-59, e-mail: itepkrak@itep.edu.pl

\begin{abstract}
During the period of 1995-2005 in the mountain areas of southern Poland (Western Carpathians), in the catchment areas of the Upper Dunajec River basin in particular, significant structural changes took place. The share of arable lands decreased in the range of $17.7-27.6 \%$ of the total area. Simultaneously the area of permanent grasslands (meadows and pastures) has increased from 9.8 to $21.1 \%$.

The objective of the work was an assessment of biogenic ingredients content $\left(\mathrm{N}^{-} \mathrm{NH}_{4}, \mathrm{~N}-\mathrm{NO}_{3}\right.$, and $\mathrm{PO}_{4}$ ) in surface water on area of the Białka catchment with the domination of permanent grasslands with low production intensification based on natural fertilizers and scattering input of mineral fertilizers. In years 2002-2005 the average share of arable land amounted $16.2 \%$, pastures and meadows $83.7 \%$ and $0,1 \%$ of orchards. Studies showed that surface water quality in this catchment area was very good, in the range of the $1^{\text {st }}$ class. Mountain grasslands are fulfilling an important protective role contributing for sustain high quality of surface water.
\end{abstract}

Key words: meadows and pastures, nutrients, the environment, the Western Carpathian

\section{INTRODUCTION}

The quality of water flowing from agricultural areas is dependent on land use and the level of agricultural production. The concentration of chemical components, especially $\mathrm{N}-\mathrm{NO}_{3}$ in drainage waters from intensively fertilized arable lands, may be about 5 times higher compared to permanent grasslands (KOC et al., 1996). Similar variations of $\mathrm{N}-\mathrm{NO}_{3}$ concentration were found in lysimeter studies, between crops that required mechanical cultivation and permanent pasture (SMORON et al., 1996). The surface water quality also depends on (in addition to agricultural activities) factors associated with human activities and existence, especially rural sanitation and the plants and installations which may have a significant impact on 
the water environment (GAŁKA and STRUTYŃSKI, 2003; PAWLIK-DOBROWOLSKI, 1990; SMOROŃ and TWARDY, 2001).

The aim of this researches was an assessment of concentrations of biogenic ingredients $\left(\mathrm{N}-\mathrm{NO}_{3}, \mathrm{~N}-\mathrm{NH}_{4}\right.$ and $\left.\mathrm{PO}_{4}\right)$, the quality characteristics of the environment in surface waters of the Białka catchment area, in terms of dominance of permanent grassland with low intensification of production based on natural fertilizers, with very little fertilizer. Additionally, the properties of the water outflow from the micro-catchment was defined which is under heavy anthropogenic activities associated with living conditions of residents.

\section{MATERIAL AND METHODS}

The studies were conducted in 2002-2007 in a highly relief Białka subcatchment forming part of the upper Dunajec catchment. Catchment of the Białka River collects water outflowing from a fragment of the High and Bielskie Tatras, and Podhale (Fig. 1). Majority fragment of this area is located in the moderative cold climatic vertical zones with the annual temperature between $4-6^{\circ} \mathrm{C}$. In the upper parts of the Tatra Mountains the temperature is maintained at a much lower level of -2 to $-1{ }^{\circ} \mathrm{C}$ (cold climatic vertical zones). The average annual amounts of precipitation from years are high and very high, ranging from $800 \mathrm{~mm}$ (Nowy Targ-Orava valley), to almost $2000 \mathrm{~mm}$ in the higher parts of the Tatra Mountains (Atlas..., 1985; NIEDŹWIEDŹ and OBRĘBSKA-STARKLOWA, 1991). The consequences of such precipitation are appreciable water resources, averaging from years in the catchment Białka -156 million $\mathrm{m}^{3} \cdot \mathrm{year}^{-1}$ (average annual flow of SSQ -5.0 $\mathrm{m}^{3} \cdot \mathrm{s}^{-1}-$ ŁANIEWSKI, 1997).

The discussed area is marked by a small share of arable land (average of about 9 per cent) and large, (30 per cent) contribution of permanent grasslands of the total area (agriculture). Forests covers the largest parts of the catchment (41 per cent). In the structure of agricultural lands of the Białka catchment the contribution of arable lands were 16.2 , pastures and meadows 83.7 , and orchards only 0.1 per cent. Low population density, amounted about 93.2 persons $\cdot \mathrm{km}^{-2}$ (population) is characteristical for that area. For several years a low-input agricultural production system caused decrease in agricultural production in this region. The stocking rate was 64 $\mathrm{LU} \cdot 100 \mathrm{ha}^{-1} \mathrm{UR}$, with ruminants constitute over 80 per cent in these. The mineral fertilization amounted about $35 \mathrm{~kg} \mathrm{NPK} \cdot \mathrm{ha}^{-1}$ UR and was sustained at low level. The base of the fertilization constitutes origin manures from livestock maintained by individual farmers.

In the Białka catchment the five water sample points was determined for chemical analysis (Fig. 1). Point No. 1 - branch water of Brzegi stream. This is an uninhabited area with the contribution of forests ranged up to 80 per cent and permanent grasslands -20 per cent. Point No. 2 is situated in lower part of the Brzegi 


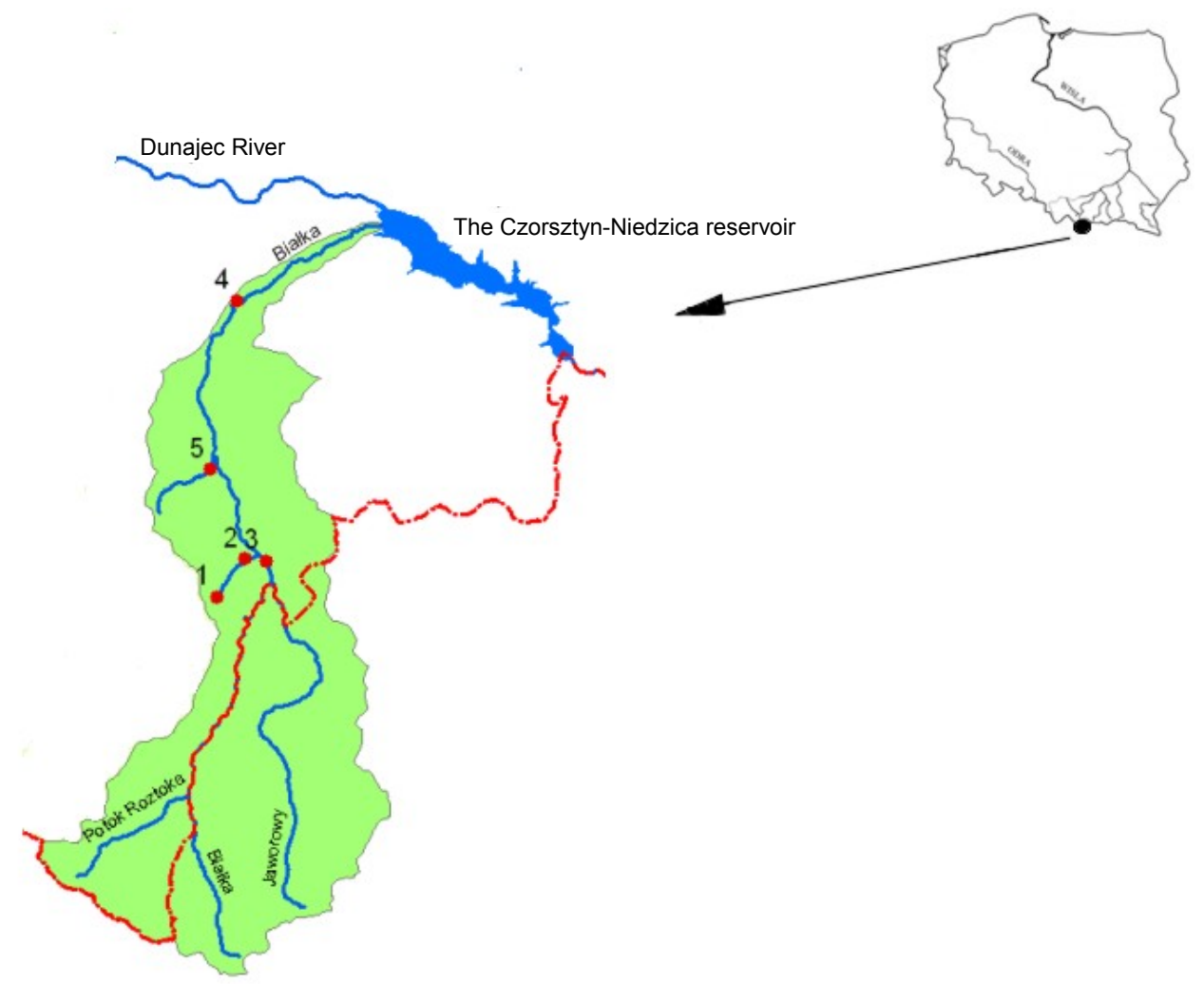

Fig. 1. Part of the upper Dunajec basin with marked 5 water sample points of Białka River basin

stream catchment, distanced from the point No. 1 about $2.8 \mathrm{~km}$. This fragment of the catchment is dominated by grasslands and forests. Strong anthropopression, which is connected with living over 1000 people on a small area and a big concentration of livestock buildings and manure storage facilities in direct neighbouring of the stream is characteristic for that fragment. In point No. 3 waters from the Białka River flows from areas in 95 per cent uninhabited and thickly wooded. Point No. 5 (Kaniowski stream), float waters from area covered in 90 per cent by grasslands with few farms. On the area situated in the region of point No. 4, on Białka River near the influx to "Czorsztyn-Niedzica" reservoir), is covered by permanent grasslands in 55 per cent and arable lands 25 per cent.

From various points at monthly intervals water samples were collected to the chemical analysis, which were made in the MOB ITP laboratory in Kraków. Concentrations of $\mathrm{N}-\mathrm{NO}_{3}, \mathrm{~N}-\mathrm{NH}_{4}, \mathrm{PO}_{4}$ were assessed; generally applied methods were assays. Results of chemical analysis were summarized as an annual average from each year and for the whole research period. Dispersion of chemical indicators around the average (standard deviation $S D$ ) was also shown. 


\section{RESULTS AND DISCUSSION}

In the respect of the analysed components, the best quality of water was featured in point No. 1, from Brzegi stream source areas (Fig. 2, 3, 4). The concentration of $\mathrm{PO}_{4}$ and $\mathrm{N}-\mathrm{NH}_{4}$ was at the lowest level in relation to the other measure points, and was on average 0.03 and 0.06 and $0.51 \mathrm{mg} \cdot \mathrm{dm}^{-3}$ for $\mathrm{N}-\mathrm{NO}_{3}$ from the studied period. The maximum monthly concentration values of the whole studied period for mentioned chemical components didn't overdrawn respectively 0.11 , $0.19,1.03 \mathrm{mg} \cdot \mathrm{dm}^{-3}$. In point No. 2, according to other measuring points, the water had the worst quality. The average concentration of $\mathrm{N}-\mathrm{NH}_{4}, \mathrm{~N}-\mathrm{NO}_{3}$, and $\mathrm{PO}_{4}$ to the relevant period was: $0.18,1.71$ and $0.25 \mathrm{mg} \cdot \mathrm{dm}^{-3}$, and maximum respectively, $0.45,2.14$ and $1.04 \mathrm{mg} \cdot \mathrm{dm}^{-3}$.

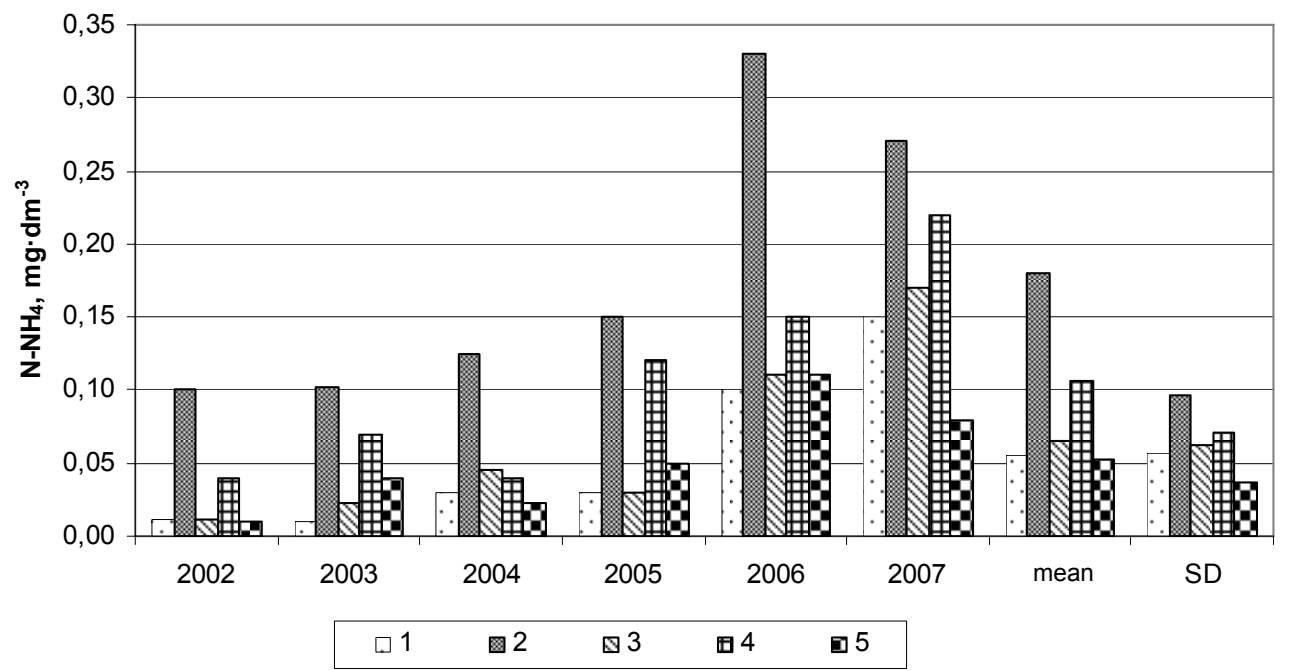

Fig. 2. The average concentration of N-NH$\left(\mathrm{mg} \cdot \mathrm{dm}^{-3}\right)$ in water: 1 - Brzegi stream - the source,

2 - Brzegi stream the mouth, 3 - Białka before reaching Brzegi stream, 4 - Białka-Trybsz, 5 - Kaniowski stream in 2002-2007 and the standard deviation value $S D$

Slightly worst quality in relation to No. 1 point, had waters of Białka River (point No. 3), above the mouth of the Brzegi stream. It was determined mainly by phosphates, which concentration was more than twice bigger, and amounted 0.07 $\mathrm{mg} \mathrm{PO}_{4} \cdot \mathrm{dm}^{-3}$ (and maximum reached 0.45 ).

In further considered tributary of the Białka River - Kaniowski stream (point No. 5), where waters were flowing from land used as a permanent grasslands, average concentration of $\mathrm{N}-\mathrm{NH}_{4}, \mathrm{~N}-\mathrm{NO}_{3}, \mathrm{PO}_{4}$ was similar to listed in point No. 3. The maximum concentration recorded over the whole study period was respectively: $0.25,0.93$ and $0.14 \mathrm{mg} \cdot \mathrm{dm}^{-3}$. 


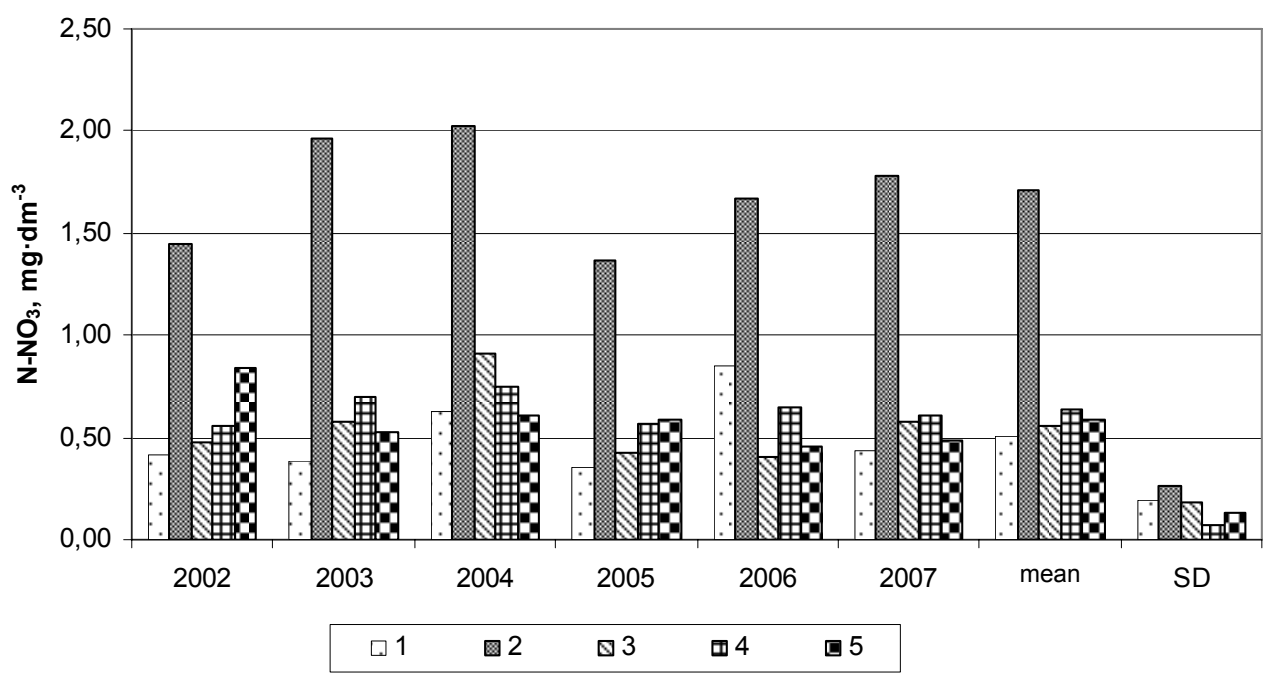

Fig. 3. The average concentration of $\mathrm{N}-\mathrm{NO}_{3}\left(\mathrm{mg} \cdot \mathrm{dm}^{-3}\right)$ in water: 1 - Brzegi stream - the source, 2 - Brzegi stream the mouth, 3 - Białka before reaching Brzegi stream, 4 - Białka-Trybsz, 5 - Kaniowski stream in 2002-2007 and the standard deviation value $S D$

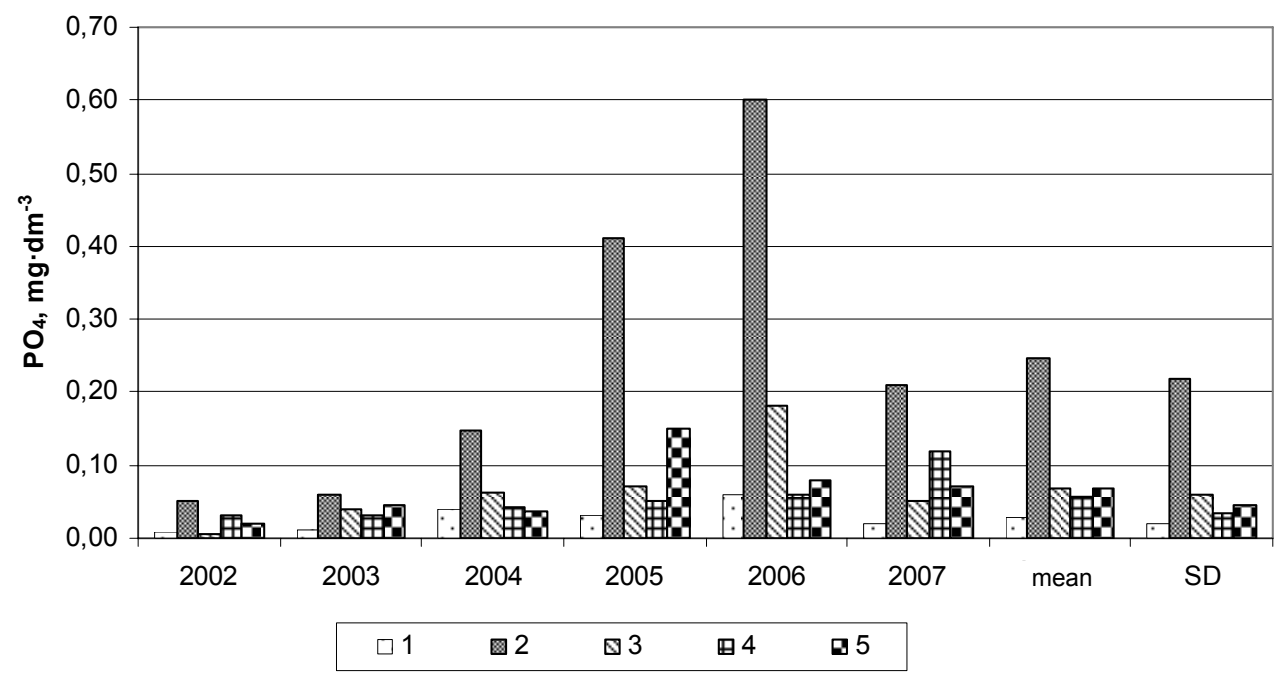

Fig. 4. The average concentration of $\mathrm{PO}_{4}\left(\mathrm{mg} \cdot \mathrm{dm}^{-3}\right)$ in water: $1-$ Brzegi stream - the source, 2 - Brzegi stream the mouth, 3 - Białka before reaching Brzegi stream, 4 - Białka-Trybsz, 5 - Kaniowski stream in 2002-2007 and the standard deviation value $S D$

In subsequent course of the Białka River, carrying water from the above subbasin (point No. 4 - village Trybsz), the average concentration of $\mathrm{N}^{-\mathrm{NH}_{4}}$ was amounted at 0.11 and $\mathrm{N}-\mathrm{NO}_{3}-0.64 \mathrm{mg} \cdot \mathrm{dm}^{-3}$. The maximal concentration of these 
components was at: 0.31 and $1.37 \mathrm{mg} \cdot \mathrm{dm}^{-3}$. The average concentration of $\mathrm{PO}_{4}$ was amounted at 0.06 , and the maximum monthly recorded concentration was on 0.30 $\mathrm{mg} \cdot \mathrm{dm}^{-3}$.

Conducted studies allowed to determine the quality of surface water running off mountain areas heavily relief, characterized by a very high contribution of forests, permanent grasslands, in slight participation of arable lands, and different anthropopression. The concentration of components in catchment waters dominated by grasslands (point No. 5), was maintained at low level, and was comparable (especially in terms of nitrogen and phosphate contents), to the one from source waters of the Brzegi stream (point No. 1), flowing through forested areas (point No. 3).

In the respect of concentration of studied components, waters were ranged in the I class of the surface water quality (Rozporządzenie... 2004). This indicates clearly that low-input production system at grasslands, based on natural fertilizers, origin from livestock, with small doses of mineral fertilizers, influenced profitably on their quality.

Determined exacerbation of the Brzegi stream water quality, was found at the mouth of the Biakka (sample point No. 2). The concentrations of $\mathrm{PO}_{4}$ at this point were 8 times and of $\mathrm{N}-\mathrm{NO}_{3}$ and $\mathrm{N}-\mathrm{NH}_{4}$ about 3 times larger than in the source part of the Brzegi stream. It was resulted in strong anthropopression associated with living a significant number of residents on a small area, who were unable to take benefit from sewerage system (PAWLIK-DOBROWOLSKI, 1990; RACZAK, 2002).

Another factor that may contribute to enriching waters in chemical components (especially N-NH${ }_{4}$ and $\mathrm{PO}_{4}$ ), is their infiltration with rainwater from manure storage facilities localised in the direct neighbourhood of the stream-bed. It concerns particularly last 3 research years, in which the rainfall in the studied area were approximately $200 \mathrm{~mm}$ higher in relation to previous years, and oscillated in the range 1057 to $1147 \mathrm{~mm}$. In these conditions, a phenomenon of surface rain wash is intensified, also washing out the components from manure storage facilities and runoff pollution from all sources into surface waters occurs more intensively (DURKOWSKI et al., 2006; SAPEK and SAPEK, 2007). This may also refer to other research areas, where the livestock is maintained, but in smaller scale.

According to mentioned Regulation (Rozporządzenie..., 2004), in whole research period water from point No. 2, in terms of $\mathrm{PO}_{4}$ concentration ranged on average in the II quality class, and in years 2005-2006 in the III quality class. For $\mathrm{N}-\mathrm{NO}_{3}$ concentrations water was classified as II quality class.

To properly define the impact of agricultural activity, with its current very low level of production, on natural environment, especially hydrous, it is necessary to consider the influence of population existence. It is of a particular meaning in strongly relief areas, especially in conditions of maladjusted level of protecting environment infrastructure to the habitants needs (SMOROŃ and TWARDY, 2001). 
This is confirmed also by PIOŚ studies, incorporating classification of surface waters, which take into consideration the level of organic and bacterial contamination. For example, the Biały Dunajec waters, which are under strong anthropogenic influence connected with masse tourists arriving to the Podhale region, are classified as the 3 quality class and are about I-II classes worse in relation to less threatened with such activities waters of Białka and Czarny Dunajec (Fig. 1, SMOROŃ and KUŹNIAR, 2006; www.nowysacz.pios.gov.pl).

In order to comparative purposes, the results of water monitoring of the surface of Szreniawa River flowing through Proszowice plateau located on the north of Krakow were presented. Soils occurring here, generated from loessial formations, are characterized by high utility value and are classified as I-IIIb bonitation classes. Arable lands are of almost $91.3 \%$, while permanent grassland only 7.6 per cent (SMOROŃ et al., 2009). The root crops, vegetables and industrial crops are intensively cultivated. The results of assessment of water quality for this area, from years 1999-2006, in range of $\mathrm{N}-\mathrm{NH}_{4}, \mathrm{~N}-\mathrm{NO}_{3}$, and $\mathrm{PO}_{4}$, were given by the Malopolska Inspectorate for Environmental Protection in Krakow.

Concentration of components collected from the waters of Szreniawa catchment, located on the Proszowice plateau, flowing from areas with very high proportion of arable lands, was significantly higher in relation to components recorded in the Białka River catchment. The average concentration of $\mathrm{N}_{-} \mathrm{NH}_{4}$ in years 1999 2006 amounted 0.73 (at $S D-0.46$ ), $\mathrm{N}_{-\mathrm{NO}_{3}}-4.10$ (at $S D-0.44$ ), and $\mathrm{PO}_{4}-0.47$ $\mathrm{mg} \cdot \mathrm{dm}^{-3}$ (at $S D-0.15$ ). The maximum recorded monthly concentration of the discussed components in the Szreniawa waters in the research period amounted respectively: $2.39,5.59$ and $0.89 \mathrm{mg} \cdot \mathrm{dm}^{-3}$.

Outflowing waters from mentioned Szreniawa catchment, located on the Proszowice plateau, with very high contribution of arable land, small contribution of permanent grasslands and intensive root crops cultivation, requiring mechanical soil cultivation, were much poorer quality. Average annual concentrations of $\mathrm{N}-\mathrm{NH}_{4}$ in relation to the Biakka River water flowing from areas dominated by grasslands were 15 times larger, $\mathrm{N}-\mathrm{NO}_{3}$ and $\mathrm{PO}_{4}$ about 7 times larger. In the case of cultivation bolt, the agricultural areas are not fully covered by vegetation, which conduce to water erosion process, escalating penetration of nutrients into ground waters. This is probably one of the reasons of high components concentrations in relation to areas with high grasslands contribution.

\section{CONCLUSIONS}

1. The water quality of Białka River catchment from the source areas of water courses, woodlands and dominated by permanent grasslands, is characterized by a low components concentrations, which classifies them in the range of I class of the surface water quality. 
2. The basic factor significantly deteriorating water quality especially in terms to phosphate, and nitrate nitrogen in some fragments of analysed region, was anthropopression caused by high population density and livestock buildings located nearly watercourses.

3. Quality of waters flowing from areas with a large contribution of permanent grassland was much better in relation to water from areas dominated by arable lands, therefore grasslands as mountain areas dominants has a crucial meaning in protection of the natural environment, in particular the water environment.

\section{REFERENCES}

1. Atlas Tatrzańskiego Parku Narodowego, 1985. (Atlas of the Tatra National Park). Ed. K. Trafas. Zakopane-Kraków, TPN: 1-32.

2. Durkowski T., BurCZYK P., KrÓlak B., 2006. Ocena odpływu składników nawozowych ze zlewni rolniczych jeziora Miedwie w okresie restrukturyzacji rolnictwa. (Assessment of nutrient runoff from agricultural catchment of Lake Miedwie during agricultural restructuring). Woda Środowisko Obszary Wiejskie, 6, 2(18): 51-63.

3. GAŁKA A., StRUTYŃSKi J., 2003. Zanieczyszczenia antropogeniczne i charakterystyka jakościowa wód powierzchniowych w przekroju badawczym Kraków-Korczowa. (Anthropogenic pollution and qualitative characterization of the surface waters in the cross-section KrakówKorczowa). Zeszyty Naukowe AR Kraków, Inżynieria Środowiska, 24: 303-315.

4. Ludność. (Population). www.stat.gov.pl. GUS.

5. ŁANIEWSKI J., 1997. Czorsztyn. Gospodarka Wodna, 12: 384-390.

6. Koc J., CiećKo Cz., JANickA R., Rochwerger A., 1996. Czynniki kształtujące poziom mineralnych form azotu w wodach obszarów rolniczych. (Factors determining minimum level of mineral nitrogen forms in water of the agricultural areas). Zeszyty Problemowe Postępów Nauk Rolniczych, 440: 175-183.

7. Niedźwiedź T., ObrębSKa-Starklowa B., 1991. Klimat. W: Dorzecze Górnej Wisły. Cz. 1. (Climate. In: The Upper Vistula Basin. Part 1.). Eds. I. Dynowska, M. Maciejewski. Warszawa Kraków, PWN: 68-84.

8. SAPEK A., SAPEK B., 2007. Zmiany jakości wody i gleby w zagrodzie i jej otoczeniu w zależności od sposobu składowania nawozów naturalnych. (Changes in water and soil quality in the farm and its surroundings, depending on the storage method of natural fertilizers). Zeszyty Edukacyjne 11. Falenty, Wydaw. IMUZ: 1-114.

9. SmOroń S., Kopeć S., MiszTal A., 1996. Dynamika azotanów w wodach infiltrujących przy różnych uprawach rolniczych. (The dynamics of nitrates in waters infiltrating at different method of agricultural cultivations). Zeszyty Problemowe Postępów Nauk Rolniczych, 440: 367-374.

10. SMOROŃ S., KuŹNIAR A., 2006. The seasonal changes of a surface water quality in the tourist areas of the Podhale (the western Carpathians). Polish Journal of Environmental Studies, 15, 5: 90-93.

11. SMOROŃ S., Twardy S., 2001. Wstępna ocena gospodarki wodno-ściekowej w rolniczoturystycznych rejonach górnej zlewni Dunajca. (Preliminary evaluation of domestic and waste water management in the agro-tourist regions of the upper Dunajec catchment). Inżynieria Rolnicza, 8: 223-237.

12. Smoroń S., KowalczyK A., Kostuch M., 2009. Użytkowanie gruntów zlewni Szreniawy w kontekście ochrony gleby i wody w latach 1995-2005. (Szreniawa catchment land use in the 
context of soil and water conservation in 1995-2005). Woda Środowisko Obszary Wiejskie, 9, 3(27): 167-179.

13. PAWLIK-Dobrowolski J., 1990. Źródła substancji chemicznych w zlewni, ich klasyfikacja i metody obliczania. W: Zanieczyszczenia obszarowe w zlewniach rolniczych. (Sources of chemicals in the catchment, their classification and methods of calculation. In: Contaminants in agricultural catchments area). Materiały Seminaryjne, 26. Falenty, IMUZ: 7-15.

14. RACZAK J., 2002. Obciążenie zbiornika czorsztyńskiego substancjami biogennymi. (The load of biogenic components in Czorsztyński Reservoir). Gospodarka Wodna, 10: 428-431.

15. Rolnictwo. (Agriculture). http://www.stat.gov.pl

16. Rozporządzenie Ministra Środowiska w sprawie klasyfikacji do prezentowania stanu wód powierzchniowych i podziemnych, sposoby prowadzenia monitoring oraz sposobu interpretacji wyników i prezentacji stanu tych wód z dnia 11 lutego 2004. (Regulation of the Minister of Environment, concerning classification of the quality of surface waters and ground waters, the method of monitoring, interpreting and presentation results from 11 February 2004). Dz. U. 32 poz. 284.

17. www.nowysacz.pios.gov.pl - Webpage of WIOŚ in Kraków - Branch in Nowy Sącz

\section{STRESZCZENIE}

\section{Znaczenie użytków zielonych dla środowiska wodnego Karpat Zachodnich (na przykładzie zlewni górnego Dunajca)}

Słowa kluczowe: biogeny, Karpaty Zachodnie, użytki zielone, woda

W latach 1995-2005 doszło na obszarach górzystych Polski Południowej (Karpaty Zachodnie), zwłaszcza w zlewni górnego Dunajca, do istotnych zmian strukturalnych. Udział gruntów ornych zmniejszył się od 17,7 do $27,6 \% \mathrm{w}$ powierzchni ogólnej. Równocześnie zwiększył się obszar trwałych użytków zielonych (łąk i pastwisk) - od 9,8 do 21,1\%. Nastapiła także ekstensyfikacja produkcji pasz na użytkach zielonych oraz zmniejszenie pogłowia bydła i owiec.

Celem badań była ocena zawartości składników o charakterze biogennym $\left(\mathrm{N}-\mathrm{NO}_{3}, \mathrm{~N}-\mathrm{NH}_{4} \mathrm{i} \mathrm{PO}_{4}\right)$ w wodach powierzchniowych na terenie zlewni „Białka” w warunkach dominacji trwałych użytków zielonych o niskiej intensyfikacji produkcji, opartej na nawozach naturalnych, z niewielkim udziałem nawozów mineralnych. W latach 2002-2005 udział gruntów ornych wynosił tu średnio 16,2, pastwisk i łąk 83,7, a sadów tylko 0,1\%. Badania wykazały, że jakość wód powierzchniowych tej zlewni była bardzo dobra i mieściła się najczęściej w I klasie. Górskie użytki zielone pełnią ważną rolę ochronną, przyczyniając się do utrzymania wysokiej jakości wód powierzchniowych. 